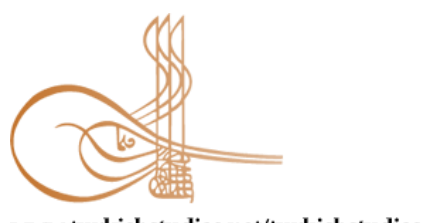

www.turkishstudies.net/turkishstudies

\section{Turkish Studies}

eISSN: $1308-2140$

Research Article / Araştırma Makalesi

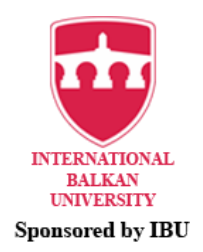

Sponsored by IBU

\title{
Doğal Afetleri Anlamlandırma ve Başa Çıkma: Covid-19 Salgını Üzerine Bir Araştırma
}

\author{
Making Sense of Natural Disasters and Coping: A Study on Covid-19 Outbreak in Turkey
}

\author{
Hasan Kaplan* - Kenan Sevinç** - Nihâl İşbilen ${ }^{* * *}$
}

\begin{abstract}
As in the whole world, the Covid-19 outbreak has affected the lives of people from age seven to seventy in Turkey and is still affecting in various dimensions. In the context of Turkey, it has been observed that three issues are clearly on the public agenda during the pandemic: (1) perception and meaning of the Covid-19 outbreak, (2) measures to control the outbreak and attitudes towards these measures, (3) ways of coping with the risk of infection and pandemic related restrictions. This descriptive study deals with these three issues in the context of religion and religiosity. The aim of the study is to examine how Turkish people perceive and make sense of Coronavirus outbreak and what coping strategies they prefer. We developed an online survey tool using Google Forms in line with the subject and purpose of the research. The survey form consists of 47 questions and 7 different sections. Items were mostly composed of Likert types and participants were asked to score each statement between 1 (Strongly Disagree) and 5 (Strongly Agree). Ethical approval for the research was obtained from the Ethics Board of ibn Haldun University (04/16/2020, 2020/12-1). The data was collected online then transferred to the SPSS package program in a computer environment and subjected to various analyses. Our findings show that the Covid-19 pandemic was taken seriously by most of the participants. A third (30\%) of the respondents approve conspiracy theories that political or economic global manipulation is behind the Coronavirus outbreak, while nearly the same percentage $(29 \%)$ believe that the outbreak is a manifestation of divine judgement. In the context of this question, just over a fifth (22\%) of the respondents stated that Coronavirus does not have any special meaning other than that it is a natural epidemic. Finally, only $9 \%$ of the respondents clearly believe that the outbreak is a form of divine punishment. Regarding the ways of coping, almost all of the respondents (98.6\%) follow coronavirus measures such as "stay at home," "hygiene," and "social distancing". The majority of the participants (86\%) resort to prayer, worship and chanting to cope with fear, anxiety and stress caused by the Coronavirus, while a third (28.2\%) of the participants cope by trying to be positive. Nearly all of the participants $(88.2 \%)$ stated that people need "spiritual support" during difficult times and pandemics such as the Coronavirus.
\end{abstract}

\footnotetext{
* Prof. Dr., İbn Haldun Üniversitesi, İslami İlimler Fakültesi, Din Bilimleri Bölümü Professor, Ibn Haldun University, Faculty of Islamic Studies, Department of Religious Studies ORCID 0000-0001-6879-5100

hasan.kaplan@ihu.edu.tr

** Doç. Dr., Çanakkale Onsekiz Mart Üniversitesi, İlahiyat Fakültesi, Felsefe ve Din Bilimleri Bölümü

Asst. Prof., Çanakkale Onsekiz Mart Universty, Faculty of Divinity, Department of Philosophy and Religious Studies ORCID 0000-0002-6726-9827

kssevinc@gmail.com

**** Doktora Öğrencisi, Marmara Üniversitesi, İlahiyat Fakültesi, Felsefe ve Din Bilimleri Bölümü PhD Candidate (ABD), Marmara University, Faculty of Divinity, Department of Philosophy and Religious Studies ORCID 0000-0001-6398-8093

nihalisbilen@gmail.com

Cite as/ Atıf: Kaplan, H., Sevinç, K, İşbilen, N. (2020). Doğal afetleri anlamlandırma ve başa çıkma: Covid-19 salgını üzerine bir araştırma. Turkish Studies, 15(4), 579-598. https://dx.doi.org/10.7827/TurkishStudies.44477

Received/Geliș: 23 June/Haziran 2020

Accepted/Kabul: 10 August/Ağustos 2020

Copyright $(\mathrm{C}$ MDE, Turkey
} 


\section{Structured abstract: Introduction / Purpose}

The Covid-19 outbreak continues to affect all of our lives from age seven to seventy. Depending on how it touches one's life, people tend to perceive and make sense of the global pandemic in different ways. In the context of Turkey, it is observed that three issues have clearly been on the agenda during the outbreak; (1) the perception and meaning of the Covid-19 outbreak, (2) the measures to control the outbreak and the attitudes towards these measures, (3) strategies to deal with the risk of becoming infected. The aim of this study is to examine how Turkish people perceive and make sense of the ongoing Coronavirus pandemic according to socio-demographic variables; what coping strategies they prefer and how religion and religiosity are involved in this process.

Within the context of the data obtained from the field, this study seeks to answer the following five questions:

1. How do Turkish people perceive the Covid-19 outbreak?

2. How do Turkish people make sense of the Covid-19 pandemic?

3. How do people in Turkey cope with the risk of themselves or their relatives becoming infected with Coronavirus?

4. How does the Turkish public feel about Covid-19 measures?

5. How is the covid-19 outbreak affecting/transforming the lives of people in Turkey?

\section{Method and Sample}

This research is a descriptive study; a quantitative online survey was conducted using an online access panel. Ethical approval for the research was obtained from the Ethics Board of ibn Haldun University.

The research was conducted online via Google Forms. The survey was completed by 3597 people over the age of 18 residing in different cities of Turkey. The sample was obtained by random participation in the online form published on the internet without selection. $72.1 \%$ of the participants $(n=2595)$ are female and $27.9 \%(\mathrm{n}=1002)$ are male. The age range of the sample is 18 to 89 , and the average age of the participants is $36.25(\mathrm{SD}=11,006)$. According to the age groups, the majority of participants are in the 25-34 age range $(30.1 \%)$, followed by the $35-44$ age range $(29.6 \%)$. In this sense, the majority of participants are young adults. Other data for the participant profile are included in Table 1 . When we look at the data, it is seen that the majority of participants have an undergraduate degree $(49.1 \%)$, are middle class in terms of income levels $(58 \%)$ and are mostly married $(63.9 \%) .55 .3 \%$ of the respondents lives in a large city and $29.6 \%$ lives in a city at the provincial level, indicating very little turnout from the rural region. In terms of religiosity, $57 \%$ of respondents describe themselves as religious and approximately the same percentage $(56 \%)$ of respondents stated that they worship regularly.

\section{Data Collection Tools}

We developed an online survey form using Google Forms in line with the subject and purpose of the research. The survey form consists of 47 questions and 7 different sections (Coronavirus perception, Coronavirus measures, Coronavirus effects, ways of coping with Coronavirus, trust in authorities, religiosity and demographic information). The survey items were mostly composed of Likert types and participants were asked to score each statement between 1 (Strongly Disagree) and 5 (Strongly Agree).

\section{Collection and Analysis of Data}

The data in this study was collected from 8th to the 18th of April 2020 via an online survey form created using Google Forms. The collected data was then transferred to the SPSS package program in a computer environment and subjected to various analyses. Since the study was descriptive, analyses were carried out by taking the frequencies and averages of the responses of the participants to demographic data questions and other survey items. The percentages of the points given in each article between 1 and 5 were calculated separately, and in order to see the general attitudes on a particular subject, the negative opinion ratio of 1 and 2 points were collected and the positive opinion ratios were calculated by collecting 4 and 5 points. In addition, cross-tables were created to see the relationship between individual perception of religiosity and various other responses, and the levels of their significance were examined by Chi-Square testing.

\section{Findings and Discussion}

Our research yielded to the following findings: 
- The majority of respondents $(68 \%)$ take the Coronavirus outbreak seriously as a natural disaster and are concerned about the possibility of catching the virus $(57.9 \%)$

- The majority (78\%) of the participants in our research reject the speculative thesis that the "Turkish gene" is resistant to Coronavirus, and almost all participants $(88 \%)$ do not accept the belief that "Coronavirus is not transmitted to those who pray regularly".

- $70 \%$ of the participants in our survey believe that our hospitals are equipped enough to fight Coronavirus, while nearly half think quarantine measures are adequate. About $50 \%$ of respondents think that economic measures are adequate and that our country has the power to overcome a Coronavirus-induced economic crisis.

- A third (30\%) of the respondents approve conspiracy theories that political or economic global manipulation is behind the Coronavirus outbreak, while nearly the same percentage $(29 \%)$ believe that the outbreak is a manifestation of divine judgement. In the context of this question, just over a fifth $(22 \%)$ of the respondents stated that Coronavirus does not have any special meaning other than that is a natural epidemic. Finally, only $9 \%$ of the respondents clearly believe that the outbreak is a form of divine punishment.

- The majority of the participants in our research have worried about losing their relatives rather than themselves, more than half of them have started to question the world and their way of life due to the pandemic, their priorities have changed, and their feelings of solidarity have increased.

- Regarding the ways of coping, almost all of the respondents (98.6\%) follow coronavirus measures such as "stay at home," "hygiene," and "social distancing". The majority of the participants (86\%) resort to prayer, worship and chanting to cope with fear, anxiety and stress caused by the Coronavirus, while a third $(28.2 \%)$ of the participants cope by trying to be positive. Nearly all of the participants $(88.2 \%)$ stated that people need "spiritual support" during difficult times and pandemics such as the Coronavirus.

\section{Conclusion and Recommendations}

In short, one of the most remarkable results in this research is that after difficult life events such as a natural disaster or disease, supernatural references often come into play. Religious beliefs are instrumental in making sense of these difficult life circumstances and overcoming the crises they generate. It appears that religious beliefs and practices occupy an important place in combatting these challenging life events. Many people think that religious and spiritual support is necessary in such cases and they try to find this support individually. Our results clearly indicate that in addition to the institutionalized services aimed at providing physical and psychological health, there is also a need for the institutionalization of service areas that aim to provide religious and moral support. it is also seen how much is needed to institutionalize a service area aimed at providing religious and moral support. In the face of such epidemics, natural disasters or other mass destructive events, it is necessary to establish teams where moral and spiritual support services can be provided quickly in an organized manner.

Keywords: Psychology of Religion, Covid-19, Natural Disasters, Religious Coping, Divine Punishment, Divine Justice, Conspiracy Theories.

Öz: Tüm dünyada olduğu gibi Covid-19 salgını Türkiye'de de yediden yetmişe herkesin hayatını etkiledi ve halen çeşitli boyutlarda etkilemeye devam etmektedir. Türkiye bağlamında Pandemi sürecinde üç konunun gündemi belirgin bir şekilde meşgul ettiği gözlemlenmektedir; (1) Covid-19 salgınına yönelik algılama ve anlamlandırma biçimleri, (2) Salgını kontrol etmeye yönelik tedbirleri ve bu tedbirlere yönelik tutumlar, (3) Enfekte olma riskiyle başa çıkma stratejileri. Bu betimsel çalışma, bu üç konuyu din ve dindarlık bağlamında ele almaktadır. Çalışmanın amacı, Türk halkının Koronavirüs salgınını nasıl algılayıp anlamlandırdığını ve hangi baş etme stratejilerini tercih ettiklerini incelemektir. Araştırmanın konusu ve amacı doğrultusunda Google Formları kullanarak çevrimiçi bir anket aracı geliştirdik. Anket formu 47 soru ve 7 farklı bölümden oluşmaktadır. Maddeler çoğunlukla Likert türlerinden oluşmuştur ve katılımcılardan her bir ifadeyi 1 (Kesinlikle Katılmıyorum) ile 5 (Kesinlikle Katılıyorum) arasında puanlamaları istenmiştir. Araştırmanın yayınlanması için İbn Haldun Üniversitesi Sosyal ve Beşerî Bilimler Bilimsel Araştırma ve Yayın Etiği Kurulu Başkanlığı'ndan16.04.2020 tarih ve 2020/12-1 sayılı Etik Onay alınmıştır. Online olarak toplanan veriler daha sonra bilgisayar ortamında SPSS paket programına aktarıldı ve çeşitli analizlere tabi tutuldu. Bulgularımız, Covid-19 salgınının katılımcıların çoğu tarafından ciddiye alındığını gösteriyor. Katılımcıların üçte biri (\%30), Coronavirüs salgınının arkasında siyasi veya ekonomik küresel manipülasyonun olduğuna dair komplo 
teorilerini onaylarken, neredeyse aynı oranda katılımcı (\%29) salgının ilahi bir imtihan olduğuna inanıyor. Bu soru bağlamında, ankete katılanların beşte birinden biraz fazlası (\%22) Koronavirüsün doğal bir salgın olduğunu, başka özel bir anlamı olmadığını ifade etmiştir. Son olarak, yanıt verenlerin yalnızca \%9'u salgının bir tür ilahi ceza olarak anlamlandırmaktadır. Başa çıkma yolları ile ilgili olarak, ankete katılanların neredeyse tamamı $(\% 98,6)$ "evde kalma", "hijyen" ve "sosyal mesafe" gibi koronavirüs önlemlerini uyguladıkları anlaşılmaktadır. Başa çıkma stratejisi olarak dua, ibadet ve zikir gibi dini ritüellere yönelimin yüksek (\%86) olduğu tespit edilen araştırmamızda ayrıca salgın sürecinde insanların manevi bir desteğe ihtiyaç duyduğu katılımcıların neredeyse tamamı (\%88) tarafından ifade edildiği tespit edilmiştir.

Anahtar Kelimeler: Din Psikolojisi, Covid-19, Doğal Afetler, Dini Başa Çıkma, İlahi Ceza, İlahi Adalet, Komplo Teorileri

\section{Giriş}

Deprem, sel ve salgın gibi doğal afetler geçmişten günümüze devam eden hayatın evrensel olgularından biridir. Doğal afetlerin bireyi, toplumu ve dünya tarihini derinden etkileyen sonuçları olmuştur. Covid-19 bağlamında an itibariyle günlük hayatımızı, iş, inanç, ilişki ve önceliklerimizi derinden etkilemeye devam eden salgın, geçmişte de insanlık üzerinde benzeri veya daha derin etkiler bırakmıştır. Örneğin Orta çağda meydana gelen, ironik bir şekilde Covid-19 gibi Çin' de ortaya çıkıp, ipek yolu üzerinden Avrupa'ya ulaşan (Ibn Al-Wardi, 2005) Kara Veba salgınının Avrupa'nın toplumsal, ekonomik, dini ve siyasi yapısını derinden etkilediği kayıtlara geçmiştir (Bennett ve Hollister, 2006: 329).

Dünya tarihinin dönüm noktalarından biri olan, kayıtlara en ölümcül salgın olarak geçen Kara Veba örneği ve sebep olduğu toplumsal kriz, değişim ve dönüşümler üzerinden hareket ederek konuyu detaylandıralım. Kaynaklar incelendiğinde tarihçilerin salgının yarattığı nüfus kaybı buna bağlı olarak ortaya çıkan kıtlık, sosyal hareketlilik, iş gücü kaybı, işçiliğin öneminin artması (buna karşın toprak sahibi olmanın değerinin azalması), serfliğin yok oluşu, karaborsacılık ve enflasyon gibi sosyo-demografik olgulara (Munro, 2005) öncelikli olarak işaret ettiği görülür (Hilton, 1974; O'Brien ve Roseberry, 1991: 25; Hanawalt, 1966: 43-44, 58). Ancak aynı kaynaklar salgın sonras1 ortaya çıkan söz konusu bu toplumsal değişim ve ekonomik krizlerin altını çizmekle beraber aynı zamanda özellikle salgının anlamlandırılmasıyla ve bu anlamlandırma biçimlerine dayalı olarak gelişen salgınla başa çıkma stratejileri, dini fanatizm, rrkçılık ve ayrımcılık gibi toplumsal (Bennett ve Hollister, 2006: 329; Boccaccio, 1930) ve siyasi krizlere (Scheidel, 2017: 292-293, 304) de yoğun bir şekilde dikkat çektikleri görülür.

Örneğin tarihsel kayıtlar, doğal afetlerin bilimsel açıklama imkân ve kapasitesinin sınırlı olduğu o dönemde, Avrupalıların Kara Veba salgınını doğaüstü güçlerle açıklayarak salgını toplumda yaygınlaşan günahlara (sapkınlık, ahlaksızlık vb.) karşılık tanrısal bir ceza olarak yorumladığını not eder (Aberth, 2010: 135; Boccaccio, 1930). Ayrıca bu anlamlandırmayla ilişkili olarak, kendini sorgulama, tövbe ve dua ederek dine yönelme gibi dini başa çıkma örneklerinin yanı sıra, Tanrı'nın neden bu kadar öfkelendiğini açıklamak için de kilisenin ve halkın "günah keçileri" ürettikleri ve özellikle Yahudileri sorumlu tutan çeşitli komplo teorilerinin ortaya atıldığı görülür (Foa, 2000:146).

Kara Veba salgınına ilişkin literatür incelendiğinde bu doğaüstü anlamlandırma biçimi ve komplo düşüncelerinin teoride kalmadığı, bir taraftan tövbe ederek Tanrı'nın merhametini cezb etmek için köy, kasaba ve şehirleri dolaşıp meydanlarda kendini kırbaçlayan "flagallentler" gibi fanatik dini akımların (Aberth, 2010: 135) ve dini içerikli çeşitli başa çıkma ritüellerinin (Horrox, 1994; Byrne, 2004: 80; Aberth, 2010) ortaya çıktığ kayıtlara geçmiştir. Diğer taraftan da getto halinde ayrı bölgelerde yaşamaları ve hijyen kuralları gereği salgına daha az yakalanmaları sebebiyle (Levy, 2005: 763) bu komplo teorilerinin daha da ileri gittiği; Yahudiler Avrupa medeniyetini ve Hristiyanlığı yıkma gayreti içinde olmakla suçlanmıştır (Gottfried, 2010: 74). Bu suçlamaya binaen 
Erfurt, Strasbourg, Cologne ve Mainz gibi Avrupa'nın çeşitli şehirlerinde yerleşik olan Yahudi halkının ayrımcılığa (Aberth, 2005) ve diri diri yakılarak (Tuchman, 1978; Foa, 2000) katliama maruz kaldıkları bazı tarihçiler tarafından iddia edilmektedir (Levy, 2005: 763; Marshall, 2006: 376).

Kara Veba salgınının üzerinden yüzyıllar geçmesine ve insanlığın bilimde ciddi mesafeler kat etmesine rağmen, yakın tarihte meydana gelen diğer doğal afetleri incelediğimizde de her ne kadar Orta Çağdaki gibi belli bir dini veya etnik grubun katliamına sebep olacak kadar ileri düzeyde olmasa da benzer algılama ve anlamlandırma biçimlerinin varlığının hala devam ettiği görülebilir. Örneğin, yaklaşık yüz y1l önce gerçekleşen 1894 büyük İstanbul depremi hakkında padişah II. Abdülhamit'i devirmek isteyenlerin tertip ettiğine ilişkin ortaya bir komplo teorisi atılmıştır (Alkan, 1999: 16). Yine 1911 yılında meydana gelen Babıali yangını feminizm akımıyla ilişkilendirilmiştir (Kaplan, 2011). 1894 büyük İstanbul depreminden yaklaşık yüzyıl sonra gerçekleşen 1999 Marmara depremi sonrasında da toplumda "ilahi adaletin tecellisi" yönünde yorumlar yapılmış, deprem yolsuzlukların, ahlaksızlıkların ve dinden uzaklaşmanın bir bedeli niteliğinde ilahi ceza olarak anlamlandırılmış, camiler dolmuş, tövbe ve dua ederek Allah'a sı̆̆ınma gibi dini başa çıkma ritüelleri zirve yapmıştır (Küçükcan ve Köse, 2000). 2004 yılında Endonezya'nın Sumatra adasının BandaAceh bölgesinde meydana gelen tsunami ve 2005 yilında meydana gelen Katrina Kasırgas1 sonrasında da benzer algılama, başa çıkma ve yorumlama biçimleri ileri sürülerek doğal afetlerin evrensel bir şekilde tanrısal bir ceza ve uyarı olarak anlamlandırıldığı ve Tanrı'nın gazabını harekete geçiren "günah keçisi" gruplar bulunarak suçlandığı görülmektedir. Örneğin, Amerikalı evanjalist vaizler Katrina Kasırgasıyla ilgili olarak feministleri, eşcinselleri ve kürtaj yanlılarını suçlamıştır (Kaplan, 2011: 20-23).

Doğal afetlerin veya genel olarak zorlu yaşam olaylarının toplumsal ve siyasi etkilerinin yanı sıra ruh sağlığı bağlamında ciddi bireysel psikolojik etkileri de vardır. Doğal afetler, hastalıklar veya sevilen bir yakının kaybedilmesi gibi zorlu yaşam olaylarından sonra somatik rahatsızlıkların ortaya çıkabildiği, stres düzeyinin arttığı, anlamsal sorgulamaların yaşandığı ve psikolojik iyi olma halinde düşüş görüldüğü bilinmektedir (Krause vd., 2016: 499-510). Zorlu yaşam olayları neticesinde meydana gelen stresle başa çıkabilmek için birey farklı yollara başvurmaktadır. Bu yollar dini veya dünyevi formlarda olabilmektedir. Din psikolojisi alanında yapılan araştırmalar, başa çıkma yolları arasında dini başa çıkmanın, yani dini inançların, dini pratiklerin ve dini mensubiyetin zorlu yaşam olayı neticesinde meydana gelen stresi azaltmakta bir araç olarak kullanılmasının oldukça yaygın ve etkili olduğunu göstermiştir (Pargament, 1997). Koronavirüs sürecinde de insanların salgının ortaya çıkardığ 1 stresin üstesinden gelebilmek için dini başa çıkma yollarına başvurmaları muhtemeldir.

Günümüzde durum nedir? Hala devam etmekte olan Covid-19 pandemisi bağlamında doğal afetler ve musibetler nasıl algılanıp anlamlandırılmakta ve insanlar bu salgınla nasıl başa çıkmaktadır? Din bu sürecin neresinde, nasıl yer almaktadır?

$\mathrm{Bu}$ araştırma, yukarıda ifade ettiğimiz temel soruların şemsiyesi altında Covid-19 salgınına ilişkin çeşitli boyutlarda sergilenen algılama, anlamlandırma ve başa çıkma süreçlerini konu edinmekte ve aşağıdaki beş spesifik soruya cevap aramaktadır:

1. Türk halkı Covid-19 salgınını nasıl algılıyor?

2. Türk halkı Covid-19 salgınını nasıl anlamlandırıyor?

3. Türkiye'deki insanlar kendilerinin veya yakınlarının Koronavirüsle enfekte olma riski ile nasıl başa çıkıyor?

4. Türk halkı Covid-19 tedbirlerine ilişkin nasıl bir tutum sergiliyor?

5. Covid-19 salgını Türkiye'deki insanların hayatını nasıl etkiledi/nasıl dönüştürdü.

\section{Yöntem}

$\mathrm{Bu}$ çalışma betimsel bir araştırma olup, araştırmada metot olarak dokümantasyon ve tarama modeli (survey) kullanılmıştır. Araştırmanın verileri anket tekniği ile internet üzerinden online olarak 
toplanmıştır. Bu çalışmada esas olarak sahadan elde edilen veriler kapsamında vatandaşlarımızın salgını nasıl anlamlandırdığı, hangi başa çıkma stratejilerini tercih ettiği, salgına ilişkin tutumları ve algıları sosyo-demografik değişkenlere göre incelenmiştir. Araştırmanın yayınlanması için İbn Haldun Üniversitesi Sosyal ve Beşerî Bilimler Bilimsel Araştırma ve Yayın Etiği Kurulu Başkanlığı'ndan16.04.2020 tarih ve 2020/12-1 sayılı Etik Onay alınmıştır.

\subsection{Katılımcilar}

Araştırmaya Türkiye'nin farklı şehirlerinde ikamet eden 18 yaş üstü 3597 kişi katılmıştır. Örneklem seçkisiz olarak, internet üzerinden yayınlanan online forma rastgele katılım ile sağlanmıştır. Araştırmanın örneklemini oluşturan katılımcıların \%72,1'i (n=2595) kadın, \%27,9'u $(\mathrm{n}=1002)$ erkektir. Katılımcıların yaş ortalaması 36,25'tir $(\mathrm{SD}=11,006)$ ve yaş aralığı 18 ile 89 arasında değişmektedir. Katılımcıların yaş gruplarına göre dağılımına bakıldığında çoğunluğunun 25-34 yaş aralığında $(\% 30,1)$ olduğu ve bunu 35-44 yaş aralığının $(29,6)$ takip ettiği söylenebilir. Bu anlamda katılımcıların çoğunluğunun genç yetişkin olduğu görülmektedir.

Tablo 1: Kat1limcilara ait demografik verilir.

\begin{tabular}{|c|c|c|c|}
\hline & & Frekans & Yüzde \\
\hline \multirow[t]{3}{*}{$\overline{\text { Cinsiyet }}$} & Kadın & 2595 & 72,1 \\
\hline & Erkek & 1002 & 27,9 \\
\hline & Toplam & 3597 & 100 \\
\hline \multirow[t]{7}{*}{ Yaş } & $18-24$ & 582 & 16,2 \\
\hline & $25-34$ & 1083 & 30,1 \\
\hline & $35-44$ & 1063 & 29,6 \\
\hline & $45-54$ & 631 & 17,5 \\
\hline & $55-64$ & 219 & 6,1 \\
\hline & 65'den büyük & 19 & ,5 \\
\hline & Toplam & 3597 & 100 \\
\hline \multirow[t]{9}{*}{ Eğitim düzeyi } & Okula hiç gitmedi & 3 & , 1 \\
\hline & İlkokul & 76 & 2,1 \\
\hline & Ortaokul & 55 & 1,5 \\
\hline & Lise & 411 & 11,4 \\
\hline & Önlisans & 377 & 10,5 \\
\hline & Lisans & 1765 & 49,1 \\
\hline & Yğksek Lisans & 657 & 18,3 \\
\hline & Doktora & 246 & 6,8 \\
\hline & Toplam & 3590 & 99,8 \\
\hline \multirow[t]{6}{*}{ Gelir düzeyi } & 1,00 & 97 & 2,7 \\
\hline & 2,00 & 386 & 10,7 \\
\hline & 3,00 & 2087 & 58,0 \\
\hline & 4,00 & 835 & 23,2 \\
\hline & 5,00 & 192 & 5,3 \\
\hline & Toplam & 3597 & 100 \\
\hline \multirow[t]{3}{*}{ Medeni hal } & Bekar & 1213 & 33,7 \\
\hline & Evli & 2297 & 63,9 \\
\hline & Toplam & 3510 & 97,6 \\
\hline \multirow[t]{5}{*}{ Yerleşim birimi } & $\overline{\text { Köy }}$ & 108 & 3,0 \\
\hline & Kasaba/İlçe & 436 & 12,1 \\
\hline & Şehir & 1065 & 29,6 \\
\hline & Büyük şehir & 1988 & 55,3 \\
\hline & Toplam & 3597 & 100 \\
\hline
\end{tabular}

Katılımcı profiline ilişkin diğer veriler yukarıdaki tabloda yer almaktadır. Eğitim düzeyi ile ilgili verilere bakıldığında katılımcıların çoğunlukla Lisans eğitimli $(\% 49,1)$ bir kitleyi temsil 
ettikleri, gelir düzeyleri bakımından orta sınıf $(\% 58)$ ve çoğunlukla evli oldukları $(\% 63,9)$ görülmektedir. Yerleşim birimi bakımından katılımcıların \%55,3'ünün büyük bir şehirde yaşadıkları ve \%29,6'sının ise il düzeyinde bir şehirde yaşadıkları görülmektedir ki bu da kırsal bölgeden katılımın çok az olduğunu göstermektedir.

Tablo 2: Katılımc1ların dindarlık düzeyleri

\begin{tabular}{lccccc}
\hline & N & Min & Max & Ort & \multicolumn{1}{c}{ SD } \\
\hline 1. Kendinizi ne derece dindar hissediyorsunuz? & 3597 & 1,00 & 5,00 & 3,6953 &, 96404 \\
2. Ne siklikla ibadet edersiniz? & 3597 & 1,00 & 5,00 & 4,1918 & 1,12604 \\
\hline
\end{tabular}

Kat1lımc1lara, kendilerini ne derece dindar hissettikleriyle ilgili 5'li Likert tipinde bir soru sorulmuş ve Tablo 2'de görüldüğü gibi ortalama olarak 3,69 düzeyinde bir bireysel dindarlık algıs1 tespit edilmiştir. $\mathrm{Bu}$ veri katılımcı kitlesinin çoğunluğunun ortalamanın üzerinde bir dindarlık düzeyine sahip olduğunu göstermektedir. İbadet etme sıklı̆g bakımından ise ortalama 4,19 puan tespit edilmiştir ki bu veri de katılımcıların çoğunluğunun hemen her gün ibadet ettiği anlamına gelmektedir. Bu veriler katılımcıların dindar bir kitle olabileceğini göstermektedir.

\subsection{Veri Toplama Araçları}

Araştırmanın konusu ve amacı doğrultusunda ülke insanımızın Koronavirüs algısını belirlemek üzere tarafımızca, Google Formlar kullanılarak, online bir anket formu geliştirilmiş ve bilgi toplama aracı olarak bu form kullanılmıştır. Anket soruları 7 farklı bölümden (Koronavirüs Algısı, Koronavirüs Tedbirleri, Koronavirüs Etkileri, Koronavirüsle Başa Çıkma, Koronavirüsle Mücadelede Kurumlara Yönelik Yaklaşım, İnanç ve Hayata Bakış ve Demografik Bilgiler) oluşmakta ve form toplamda 47 soruyu içermektedir. Maddeler çoğunlukla 5'li Likert tipinde oluşturulmuş ve katılımcıların maddelerdeki ifadelere 1 (hiç katılmıyorum) ile 5 (kesinlikle katılıyorum) arasında puan vermeleri istenmiştir. Anket formunda yer alan bazı bölümlerin detayları şöyledir:

\subsubsection{Koronavirüs Algısı}

Katılımcıların Koronavirüs salgını ile ilgili genel bilgi ve farkındalık düzeyini, salgın ve salgına ilişkin gelişmeleri algılama ve anlamlandırma tarzlarını tespit etmek için salgının başlangıcından anketin yapıldığı 8 Nisan 2020 tarihine kadar yaşanan olaylar, medyaya ve sosyal medyaya yansıyan algılar, spekülasyonlar, tartışmalar ve araştırmacıların kişisel gözlem ve deneyimleri birlikte ele alınmış, bu çerçevede 11 madde hazırlanmıştır. Bu bağlamdaki 11 maddenin ilk 10 tanesi 5'li Likert tipinde oluşturulmuştur. Örneğin, katılımcılardan "Salgınla mücadelede diğer ülkelere göre daha iyi konumdayız", "Türklerin genetik yapısı Koronavirüse karşı dayanıklıdır” ve "Namazında niyazında bir Müslümana Koronavirüs bulaşmaz" gibi medyaya yansımış tartışmalı ifadelere ne derece katılıp katılmadıklarının Likert tipi bir ölçek üzerinde 1 (hiç katılmıyorum) ile 5 (kesinlikle katılıyorum) arasında bir puan vererek belirtmeleri istenmiştir. 11. madde ise özel bir soru olup, yine özellikle Türkiye ve dünya gündemine yansıyan tartışmalı bir konuyu dikkate alarak Covid-19 salgını hakkındaki algı ve anlamlandırma biçimini daha net bir şekilde tespit etmek üzere spesifik olarak tasarlanmıştır. Katılımcılara "Aşağı ıdaki ifadelerden hangisi sizin Koronavirüs salgınıyla ilgili görüşünüze en yakın olanıdır?" sorusu sorulmuş ve cevap olarak; "Koronavirüs salgını doğanın bir intikamıdır" (Çevre hassasiyeti), "Bu salgınının arkasında siyasi veya ekonomik küresel bir manipülasyon vardır" (Komplo teorisi), "Koronavirüs doğal bir salgındır, özel bir anlam yüklemiyorum" (Bilimsel/Seküler yaklaşım) gibi seçeneklere ek olarak bu araştırmanın ana unsurunu oluşturan dini anlamlandırma literatürdeki ayrıştırmayı (Pargament, 1997) dikkate alarak iki ayrı seçenek olarak verilmiştir: "Koronavirüs İlahi bir imtihandır" (Olumlu dini anlamlandırma), "Koronavirüs İlahi bir cezadır" (Olumsuz din anlamlandırma). Ayrıca esneklik sağlaması bakımından "bir fikrim yok" seçeneği de sunulmuştur. Böylece Covid-19 salgınına yüklenen 
muhtemel anlamları ifade eden 6 ayrı seçenek sunulmuş ve katılımcıya sadece birini seçebilme imkânı tanınmıştır.

\subsubsection{Covid-19 Tedbirlerine Yönelik Tutum}

Katılımcıların pandemi sürecinde alınan tedbirleri ne derece benimseyip dikkate aldıklarını, yeterli bulup bulmadıklarını tespit etmek üzere 10 maddelik ayrı bir soru grubu hazırlanmıştır. Örneğin, katılımcılara 'Koronavirüsten korunmak için 'evde kal', 'hijyen' ve 'sosyal mesafe' gibi kurallara tüm halkımızın uyması gerekir", "Diyanet İşleri Başkanlığı tarafından camilerde cemaatle namaza ara verilmesi doğru bir karardır" ve "Devletimizin aldığ 1 karantina tedbirleri yeterlidir" gibi ifadeler verilerek, bu ifadelere ne derece katılıp katılmadıklarını 5'li Likert tipi bir ölçek üzerinde 1 (hiç katılmıyorum) ile 5 (kesinlikle katılıyorum) arasında puan vererek belirtmeleri istenmiştir.

\subsubsection{Covid-19 Salgınıyla Başa Çıkma}

Katılımcıların salgının oluşturduğu riskler ve bu süreçte alınan tedbirler (sokağa çıkamama, maske, hijyen, karantina) sebebiyle meydana gelen kısıtlamalarla nasıl başa çıktıklarını ve bu süreci nasıl yönettiklerini tespit etmek için çoğu Likert tipi ama bazıları farklı formatlarda 7 soru hazırlanmıştır. Örneğin, doğal afetlerle ilgi literatür (Küçükcan ve Köse, 2000; Pargament, 1997), bireysel deneyim ve gözlemler ve medyaya yansıyan bazı örnekler göz önünde bulundurularak formatı Likert tipinden farklı olan bir maddede katılımcılara "Koronavirüs sebebiyle yaşadığınız korku-kayg1 ve stresle baş etmede aşağıdakilerden hangisine diğerlerinden daha fazla baş vuruyorsunuz?" diye bir soru sorulmuş, cevap olarak; "Pozitif Olmak", "Dua, İbadet, Zikir Yapmak", "Spor/Egzersiz" ve bunun benzeri seçenekler verilmiştir.

Kişisel bilgi formunda katılımcıların yaş, cinsiyet, medeni durum, eğitim durumu, gelir seviyesi gibi kişisel özelliklere dair sorulara yer verilmiş, inanç ve dini davranışla ilgili de iki soru sorulmuştur. Sorulardan biri bireysel dindarlık algısını göstermek üzere katılımcının dindarlık düzeyini 1 (hiç dindar değilim) ile 5 (oldukça dindarım) arasında puanlaması şeklinde, diğeri ise ibadet sıklığını 1 (ibadet etmem) ile 5 (düzenli ibadet ederim, beş vakit namaz kılmak vb.) arasında puanlaması şeklindedir.

\subsection{Verilerin Toplanması ve Analizi}

$\mathrm{Bu}$ araştırmada veriler 8-18 Nisan 2020 tarihleri arasında, Google Formlar kullanılarak oluşturulan online anket formu ile toplanmıştır. Daha sonra toplanan veriler bilgisayar ortamında SPSS paket programına aktarılmış ve çeşitli analizlere tabi tutulmuştur. Çalışma betimsel olduğu için, araştırmaya katılanların demografik verilere ilişkin sorulara ve diğer anket maddelerine verdikleri cevapların frekansları ve ortalamaları alınarak analizler gerçekleştirilmiştir. Her bir maddeye 1 ile 5 arasında verilen puanların yüzdeleri ayrı ayrı hesaplandığı gibi, belli bir konudaki genel tutumları görebilmek adına, 1 ve 2 puanları toplanıp olumsuz kanaat oranı ve 4 ile 5 puanları toplanarak da olumlu kanaat oranları hesaplanmıştır. Ayrıca bireysel dindarlık algısını gösteren soruya verilen cevaplarla diğer çeşitli yanıtlar arasındaki ilişkiyi görmek için çapraz tablolar oluşturulmuş ve anlamlılık düzeyleri Chi-Kare testi ile incelenmiştir.

\subsection{Araştırmanın Sınırlııkları}

Araştırma, pandemi sürecinde gerçekleştirilmiştir. Bu süreçte sık sık sosyal mesafe kuralları uygulandığından ve sokağa çıkma yasakları bulunduğundan, katılımcılara internet üzerinden ulaşılması en efektif yol olarak görülmüştür. Bundan ötürü de araştırmaya, yalnızca internet erişimi ve kullanımı olan kişiler katılmıştır. Araştırmanın en önemli sınırılığı budur. Ayrıca katılımcıların profiline bakıldığında, anketin online olarak yürütülmesinden kaynaklandığı tahmin edilmek üzere, katılımcıların çoğunluğunun kadın ve eğitim düzeyinin lisans olduğu görülmektedir. Araştırmanın sonuçlarının genellenmesinde bu sınırlılıklarının dikkate alınması gerekmektedir. 


\section{Bulgular}

\subsection{Koronavirüs Algısı}

Türk halkı Covid-19 salgınını nasıl algıllyor?

Katılımcıların Koronavirüsle ilgili algılarını tespit edebilmek için, 11 soru yöneltilmiştir. İlk 10 soruda katılımcıların yer alan ifadelere 1'den 5'e kadar puan vermeleri istenmiştir. Verilen cevapların ortalama puanları alındığında (Grafik 1), araştırmada yer alanların en fazla katıldıkları ifadenin 4,57 puan ile salgın ve afetlerde insanların dini ve manevi desteğe ihtiyacı olduğu ifadesinin olduğu görülmektedir. Bunu, Koronovirüsün doğal bir afet olduğu ve bilim adamlarının bunun çaresini bulacağı fikri $(3,94)$ takip etmektedir. Araştırmada yer alanların katıldıkları diğer maddeler ise salgından sonra dünyanın değişeceği, Türkiye'nin diğer ülkelere nazaran salgınla iyi mücadele ettiği ve Koronavirüsün kişinin kendisine veya yakınlarından birisine bulaşma korkusunun olduğu ifadeleridir. Ortalamanın altında puan alan yani örneklemin katılmadığını belirttiği ifadelere gelindiğinde ise 3, 7, 8, 9 ve 10. maddeler görülmektedir. Koronavirüsle ilgili bazı uzmanların medyada yer alan iddialarına, yani kadercilik, Türk geni, geleneksel tıp ve namaz ve niyazında olmanın koruyuculuğuna ilişkin tutumlara bakıldığında (7, 9 ve 10 . maddeler), bunların olumsuz oldukları görülmektedir.

Grafik 1: Korovirüs algis1

Koronavirüs salgınıyla ilgili aşağıdaki ifadelere ne derece katılıyorsunuz?

5. Böylesi salgın ve afetlerde insanların dini ve manevi desteğe de ihtiyacı vardır.

2. Koronavirüs diğer afetler gibi doğal bir salgındır, bilim insanları ve tıp çaresini bulacaktır.

6. Salgından sonra dünya çok değişecek.

4. Salgınla mücadelede diğer ülkelere göre daha iyi konumdayız.

1. Koronavirüsün bana veya yakınlarımdan birine bulaşma ihtimali beni çok korkutuyor.

7. Geleneksel tıbbi yöntemler (nane limon, paça çorbası, şifalı bitkiler vb) Koronavirüse karşı..

8. Koronavirüse karșı hiçbir tedbir tam olarak fayda vermez, sonuçta Allah'ın dediği olur.

3. Koronavirüs salgını gereğinden fazla abartılıyor.

9. Türklerin genetik yapısı Koronavirüse karşı dayanıklıdır.

10. Namazında niyazında bir Müslümana Koronavirüs bulaşmaz.

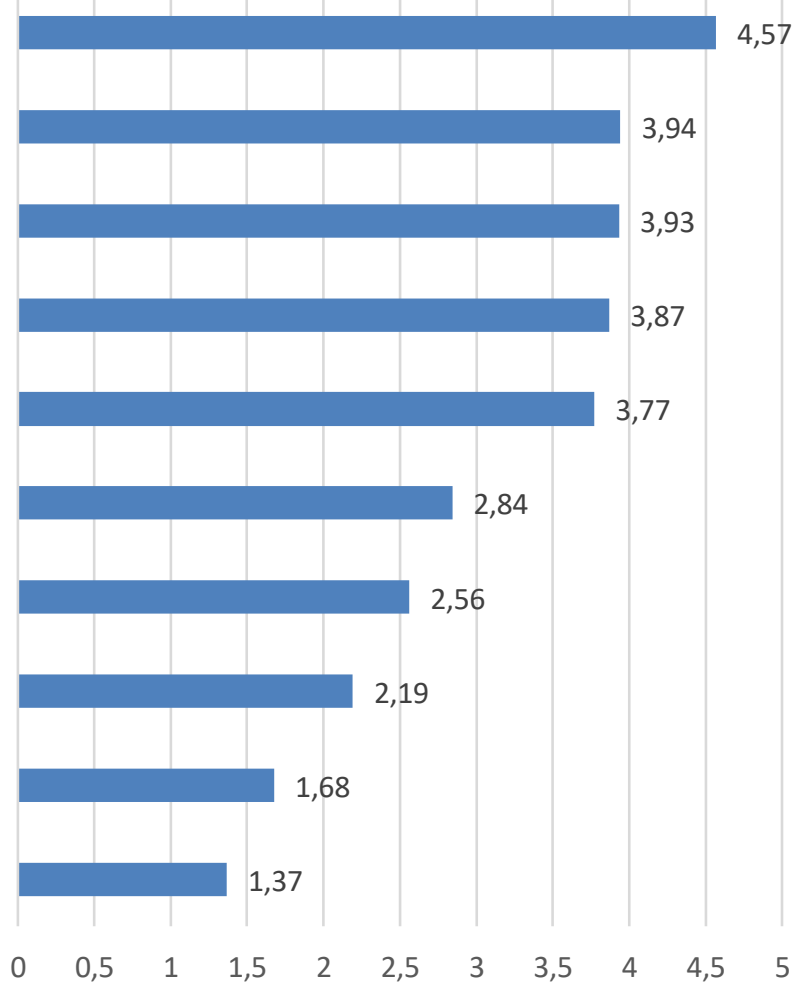

\subsection{Salgınının Anlamlandırılması}

Türk halkı Covid-19 salgınını nasıl anlamlandırıyor?

Koronavirüs algısıyla ilgili anlamlandırma biçiminin nasıl olduğunu, doğaüstücü/din eksenli atıflarda $\mathrm{m} 1$ yoksa doğalcı atıflarda $\mathrm{m} ı$ bulunulduğunu tespit etmek üzere katılımcılara bir dizi ifade 
verilmiş ve birini tercih etmeleri istenmiştir. Seçeneklerden ikisi doğalcı ve ikisi de doğaüstücüdür. Bir seçenek ise siyasi komplo teorileri ile ilgilidir. Grafik 2'de görüldügü gibi, en yüksek oran $(\% 30,6)$ "Bu salgınının arkasında siyasi veya ekonomik küresel bir manipülasyon vardır" seçeneğine aittir. Bunu daha sonra \%29,6 ile "Koronavirüs İlahi bir imtihandır" ve \%22 ile "Koronavirüs doğal bir salgındır, özel bir anlam yüklemiyorum" ifadeleri takip etmektedir. Görüldüğü gibi doğaüstücü atıfta bulunanların oranı doağc1 atıfta bulunanlara göre daha yüksektir. Öte yandan bunun ilahi bir imtihan olduğu düşünenlerin yüksek olmasına rağmen, bunun ilahi bir ceza olduğunu düşünenlerin oranı oldukça düşüktür $(\% 9,5)$.

Grafik 2: Koronavirüsün anlamlandırılması

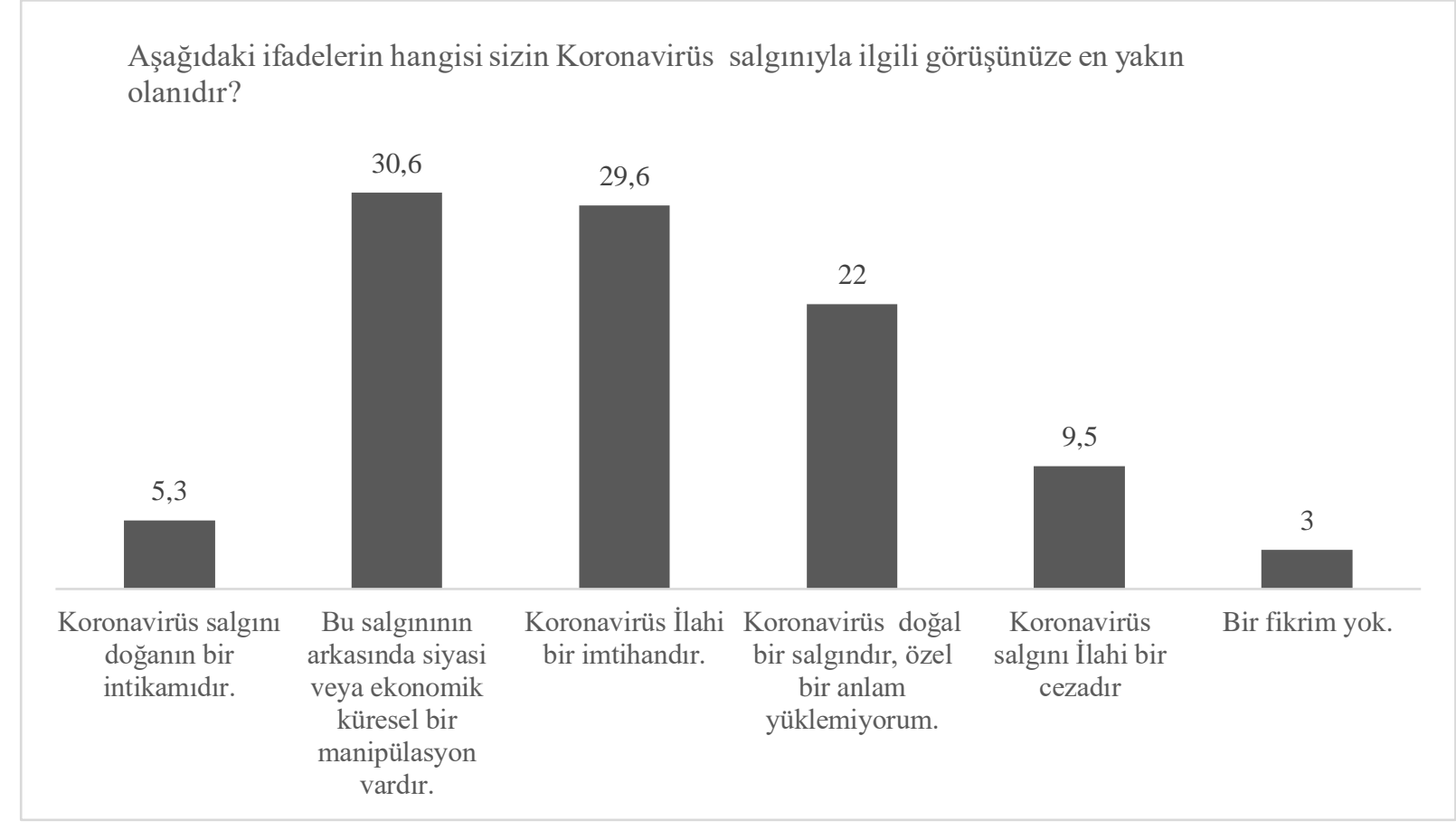

Koronavirüsün anlamlandırılma biçiminin cinsiyete, eğitim düzeyine ve dindarlık düzeyine göre nasıl değiştiği analiz edilmiştir (Tablo 2). Aşağıda görüldüğü gibi, kadın ve erkekler arasında bu konuda bazı farklılıklar dikkat çekmektedir. Virüsün doğal bir salgın olduğu ifadesine katılım oranlarına bakıldığında erkekler arasında bu ifadeye katılanların oranının (\%29,7), kadınlarınkinden (\%19) anlamlı düzeyde yüksek olduğu görülmektedir. Eğitim düzeyi ve ilgili değişken arasındaki ilişki analiz edildiğinde ise eğitim düzeyi yükseldikçe doğalcı atıfların arttığı, düştükçe doğaüstücü atıfların yükseldiği görülmektedir. Yine bu salgının ilahi bir ceza olduğunu düşünenlerin oranı eğitim seviyesi ile ters orantılı gözükmektedir. Salgının arkasında siyasi-ekonomik bir manipülasyonun bulunduğu fikri ise eğitim düzeyi yüksek olanlar arasında daha yaygındır. Son olarak dindarlık düzeyine bakıldığında, beklenildiği gibi dindarlık düzeyi arttıkça doğaüstücü atıflar da artmaktadır. 
Tablo 2: Koronavirüsün anlamlandırılmasının diğer değişkenlerle ilişkisi

\begin{tabular}{|c|c|c|c|c|c|c|c|c|c|}
\hline & & 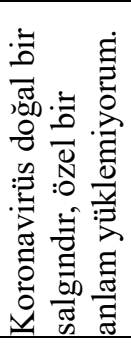 & 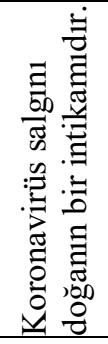 & 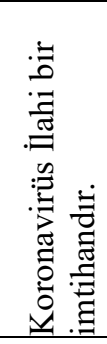 & 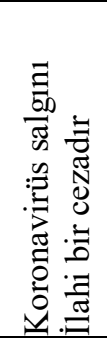 & 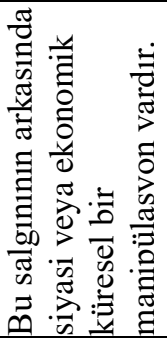 & 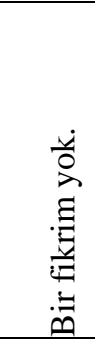 & & $\frac{\Xi}{\frac{\pi}{2}}$ \\
\hline \multirow{9}{*}{$\begin{array}{l}\text { Cinsiyet } \\
\mathrm{X}^{2}=66,202 \\
p<, 001 \\
\text { Eğitim } \\
\mathrm{X}^{2}=234,526 \\
p<, 001\end{array}$} & Kadın & $19,0 \%$ & $5,4 \%$ & $32,4 \%$ & $9,8 \%$ & $30,2 \%$ & $3,2 \%$ & $100 \%$ & \\
\hline & Erkek & $29,7 \%$ & $5,0 \%$ & $22,3 \%$ & $8,9 \%$ & $31,6 \%$ & $2,5 \%$ & $100 \%$ & \\
\hline & İlkokul & $10,5 \%$ & $7,9 \%$ & $47,4 \%$ & $17,1 \%$ & $10,5 \%$ & $6,6 \%$ & $100 \%$ & \\
\hline & Ortaokul & $7,3 \%$ & $1,8 \%$ & $54,5 \%$ & $18,2 \%$ & $18,2 \%$ & $0,0 \%$ & $100 \%$ & \\
\hline & Lise & $11,7 \%$ & $6,3 \%$ & $34,8 \%$ & $11,2 \%$ & $32,1 \%$ & $3,9 \%$ & $100 \%$ & \\
\hline & Önlisans & $15,6 \%$ & $3,7 \%$ & $36,9 \%$ & $13,8 \%$ & $28,6 \%$ & $1,3 \%$ & $100 \%$ & \\
\hline & Lisans & $20,7 \%$ & $4,9 \%$ & $29,1 \%$ & $10,1 \%$ & $32,4 \%$ & $2,8 \%$ & $100 \%$ & \\
\hline & $\begin{array}{l}\text { Yğksek } \\
\text { Lisans }\end{array}$ & $32,0 \%$ & $5,9 \%$ & $24,7 \%$ & $4,7 \%$ & $29,2 \%$ & $3,5 \%$ & $100 \%$ & \\
\hline & Doktora & $38,6 \%$ & $5,7 \%$ & $16,3 \%$ & $4,5 \%$ & $31,3 \%$ & $3,7 \%$ & $100 \%$ & \\
\hline \multirow{5}{*}{$\begin{array}{l}\text { Dindarlık } \\
\mathrm{X}^{2}=256,828 \\
p<, 001\end{array}$} & 1 & $59,1 \%$ & $12,7 \%$ & $0,0 \%$ & $1,8 \%$ & $25,5 \%$ & ,9\% & $100 \%$ & \\
\hline & 2 & $37,2 \%$ & $16,9 \%$ & $14,5 \%$ & $4,7 \%$ & $24,4 \%$ & $2,3 \%$ & $100 \%$ & \\
\hline & 3 & $23,2 \%$ & $6,0 \%$ & $26,4 \%$ & $9,7 \%$ & $31,1 \%$ & $3,6 \%$ & $100 \%$ & \\
\hline & 4 & $17,3 \%$ & $4,1 \%$ & $34,6 \%$ & $10,2 \%$ & $31,0 \%$ & $2,8 \%$ & $100 \%$ & \\
\hline & 5 & $19,3 \%$ & $2,8 \%$ & $33,5 \%$ & $10,4 \%$ & $31,2 \%$ & $2,8 \%$ & $100 \%$ & \\
\hline
\end{tabular}

\subsection{Salgınla Başa Çıkma}

Türkiye'deki insanlar kendilerinin veya yakınlarının Koronavirüse enfekte olma riski ile nasıl başa çıkıyor?

Grafik 3: Koronavirüs ile başa çıkma yolları

Koronavirüs sebebiyle yaşadığınız korku-kaygı ve stresle baş etmede aşağıdakilerden hangisine DİĞERLERINNDEN DAHA FAZLA baş vuruyorsunuz?

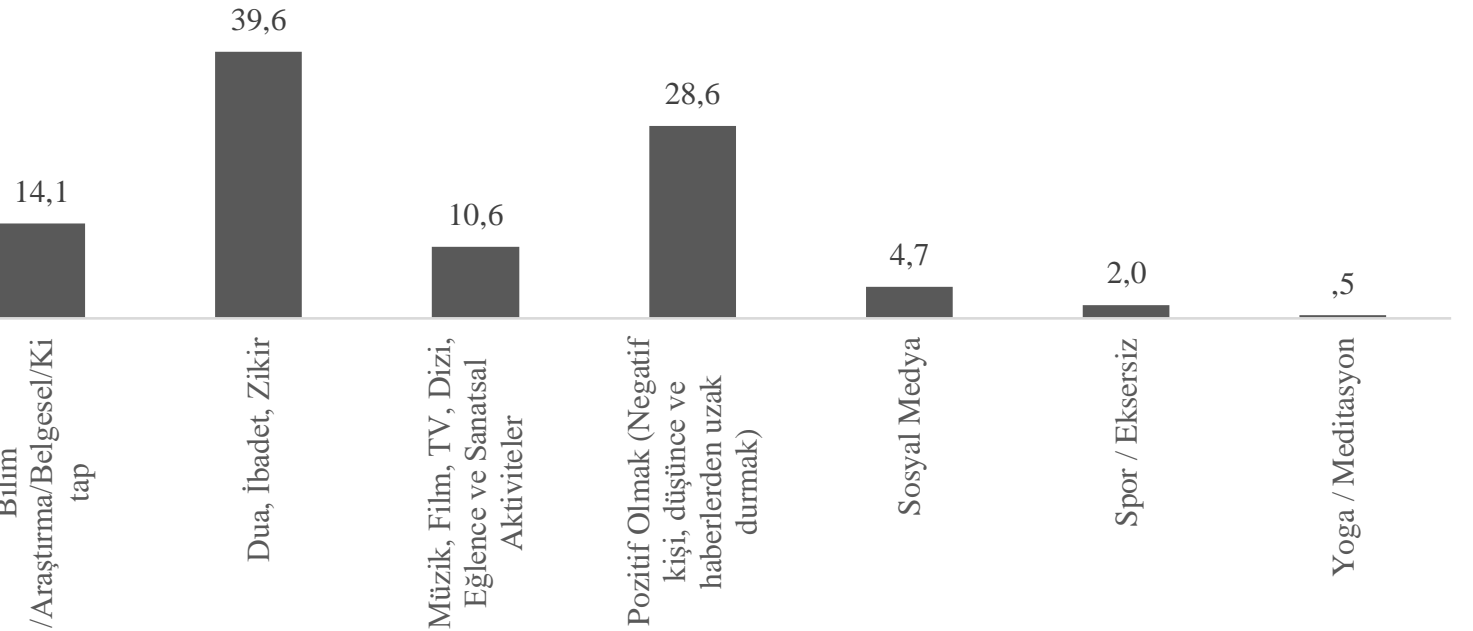


Araştırmanın en önemli amaçlarından birisi, Koronavirüsün neden olduğu kaygı ve stresle başa çıkmada bireylerin ne tür yollara başvurduklarını tespit etmektedir. Bunun için bir dizi seçenek oluşturulmuş ve katılımcıların bunlardan birisini seçmeleri istenmiştir (Grafik 3). Yukarıdaki grafikte görüldüğü gibi ilk sırada $(39,6)$ dua, ibadet ve zikir gibi dini pratikler yer almaktadır. Yani yaklaşık olarak her beş kişiden ikisinde dindarlık önemli bir başa çıkma kaynağı olarak işlev görmektedir. İkinci sırada ise \%28,6 ile "Pozitif Olmak (Negatif kişi, düşünce ve haberlerden uzak durmak)" ifadesi yer almaktadır.

Grafik 4: Koronavirüsle bireysel mücadele başvurulan dini aktiviteler

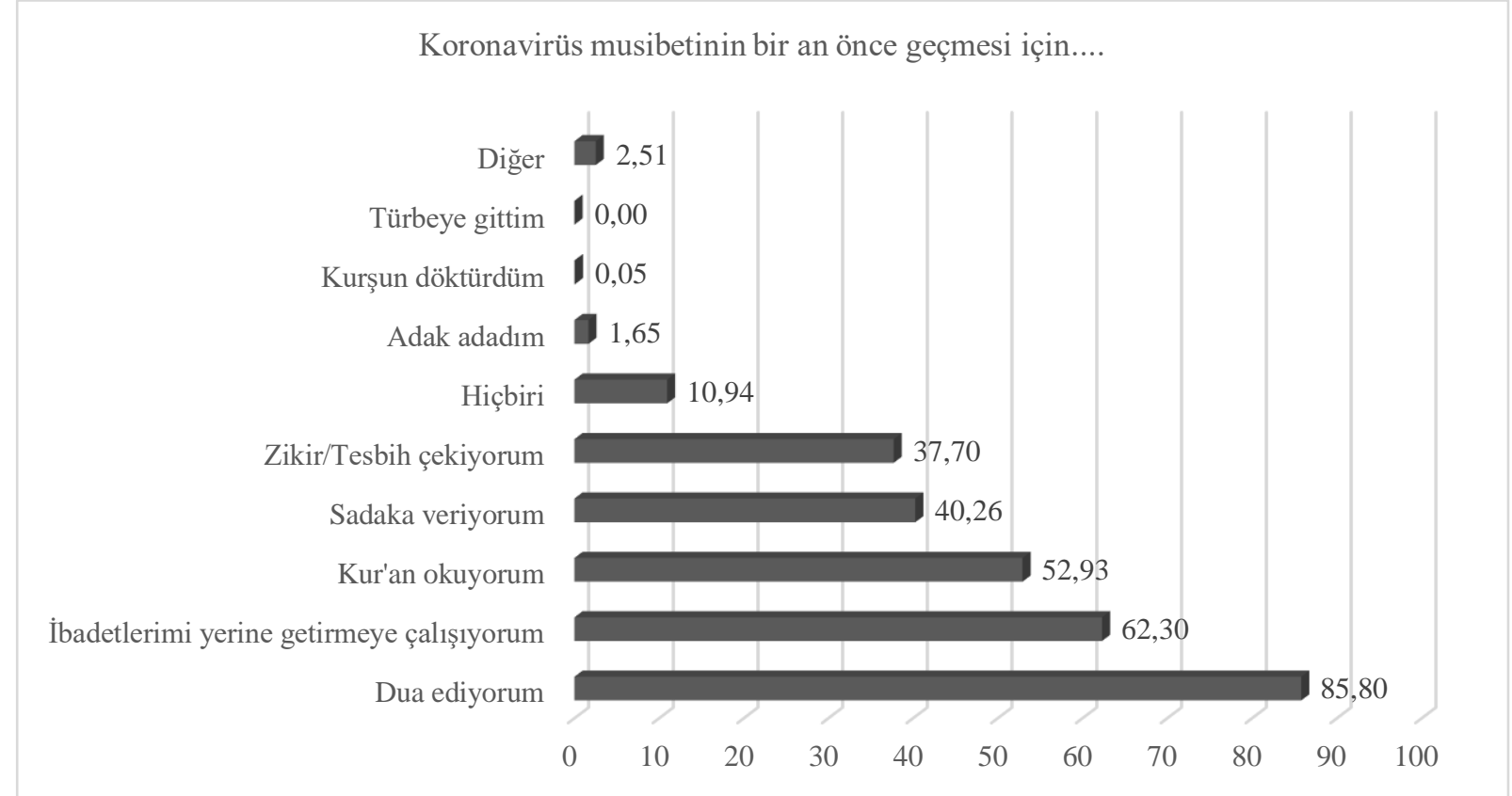

Dindarlık önemli bir mücadele kaynağı olarak görüldüğg̈ için, katılımc1lara ne tür dini aktivitelerle bu mücadeleyi gerçekleştirdikleri sorulduğunda (Grafik 4), \%85 oranında "dua ediyorum" seçeneğinin işaretlendiği görülmüş̧ür. Bunun yanı sıra yine çoğunluğun ibadet ettiğini $(\% 62,3)$ ve Kur'an okuduğunu $(\% 52,93)$ beyan ettiği görülmektedir. Yarıdan daha az katılımcı ise sadaka verdiğini $(\% 40,26)$ ve zikir çektiğini $(\% 37,7)$ belirtmiştir. 


\subsection{Koronavirüs Tedbirleri}

Türk halkı Covid-19 tedbirlerine ilişkin nasıl bir tutum sergiliyor?

Grafik 5: Koronavirüs tedbirleri

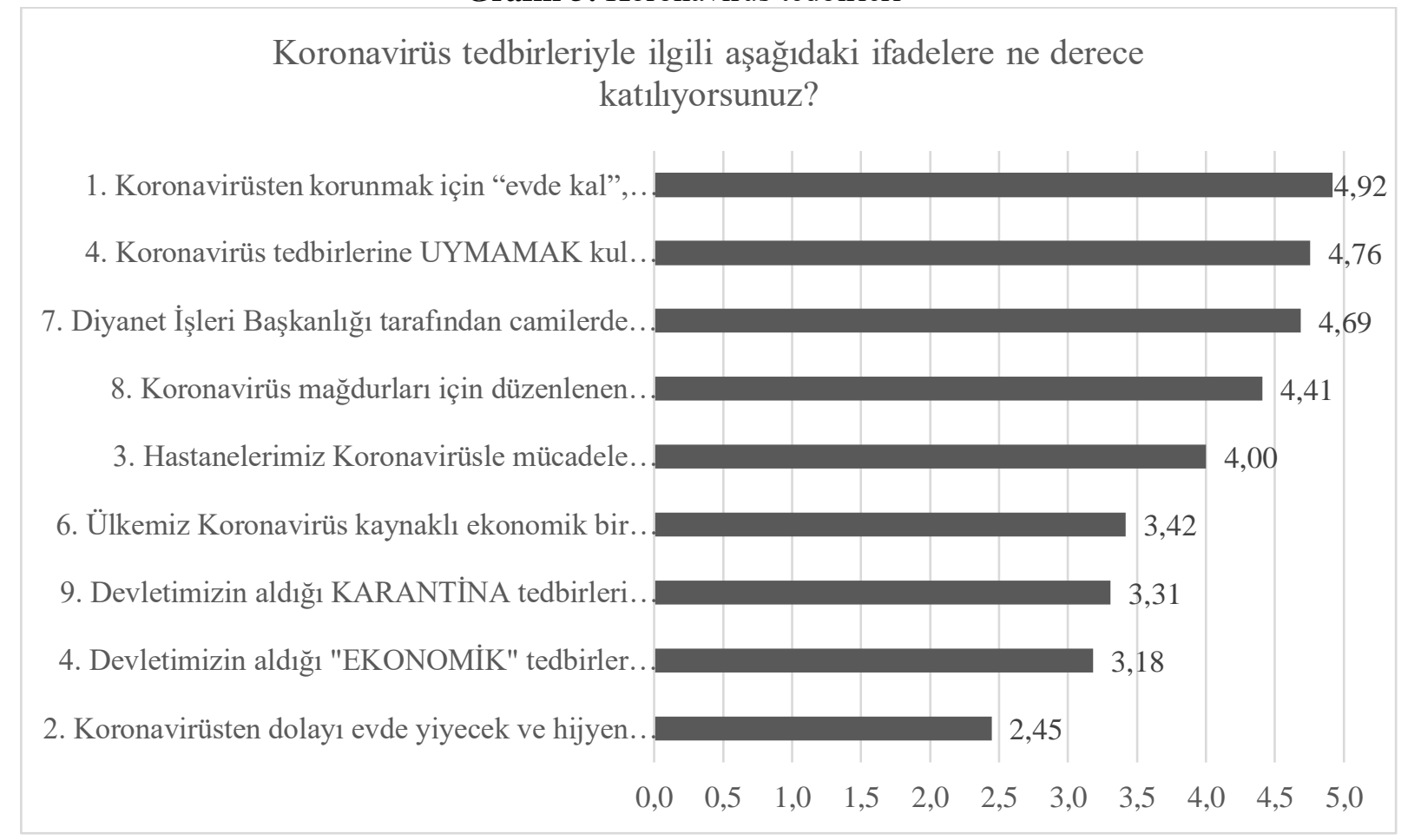

Araştırmada Koronavirüsle ilgili alınan yasal, ekonomik, sağlık tedbirleri, bunlara ilişkin algılar ve bunlara uyma düzeyleri ele alınmıştır (Grafik 5). Neredeyse katılımcıların tamamı $(4,92$ puan) "Koronavirüsten korunmak için 'evde kal', 'hijyen' ve 'sosyal mesafe' gibi kurallara tüm halkımızın uyması gerekir” ifadesine katıldıklarını belirtmişlerdir. En yüksek puanı alan ikinci madde ise bu tedbirlere uymamanın kul hakkı olduğu maddesidir. Bu sonuç dini inançların çeşitli yasal düzenlemelere uyma konusunda ne gibi etkilerde bulunabileceğine dair fikir vermektedir. Koronavirüs sürecinde en çok tartışılan konulardan birisi camilerde cemaatle namaz kılınmasına ara verilmesi kararıydı. Toplumda bu karara olumlu bakanlar olduğu gibi, olumsuz bakanlar da bulunmaktadır. Karara ilişkin genel tutuma bakıldığında ise araştırmada yer alanların büyük çoğunluğunun $(4,69)$ bu karara katıldıkları görülmektedir. Araştırma verileri, halkımızın düzenlenen yardım kampanyalarını desteklediklerini, hastanelerimizin mücadele için gerekli donanıma sahip olduklarını düşündüklerini, pandemi kaynaklı ekonomik krizi atlatacağımıza inandıklarını, alınan ekonomik ve sağlık tedbirlerini olumlu bulduklarını göstermektedir. Katılımcılar, pandemiden ötürü evde hijyen ve gıda malzemesi stoklanmasını ise yanlış bulmaktadırlar. 
Grafik 6: Koronavirüse karşı bireysel tedbirler

Koronavirüs salgınına karşı hangi bireysel tedbirleri alıyorsunuz?

Geleneksel tıbbi yöntemleri kullanıyorum (şifalı, .

Eldiven kullanıyorum

İşe gitmiyorum.

Seyahat planlarımı iptal ettim

Ellerime kolonya/dezenfektan sürüyorum

Maske takiyorum

Sosyal mesafeye dikkat ediyorum

Mecbur olmadıkça evden dişarı çıkmıyorum

Hijyen kurallarına uyuyorum

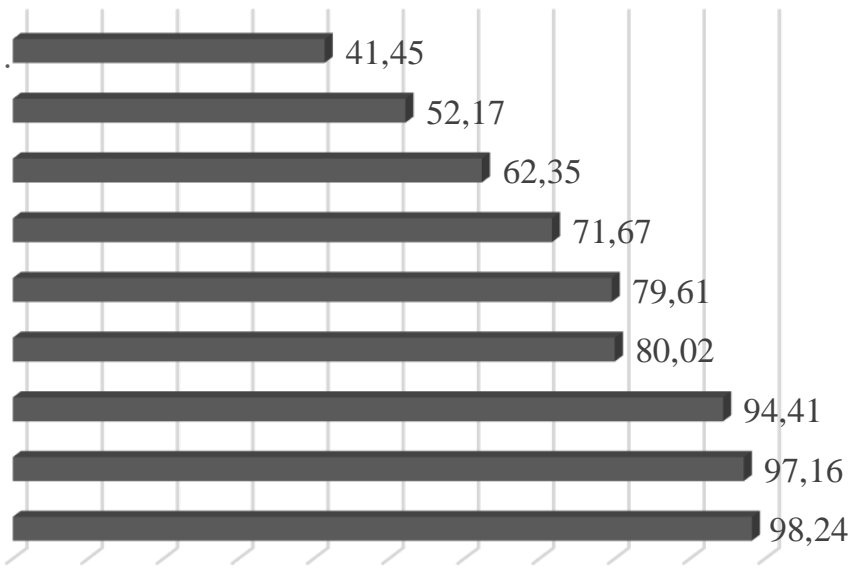

$$
\begin{array}{lllllllllll}
0 & 10 & 20 & 30 & 40 & 50 & 60 & 70 & 80 & 90 & 100
\end{array}
$$

Alınan bireysel tedbirlere bakıldığında (Grafik 6), en yüksek oranda uygulanan tedbirin hijyen kurallarına riayet etmek olduğu görülmektedir. Bunu sırasıyla evde kalma kuralına uymak, sosyal mesafeye dikkat etmek, maske takmak, dezenfektan kullanmak, seyahat planlarını iptal etmek, işe gitmemek ve eldiven kullanmak izlemektedir. Katılımcıların yarıdan daha azı geleneksel tıbbi yöntemlerle tedbir aldığını belirtmiştir.

\subsection{Koronavirüs ve Hayatın Dönüşümü}

Covid-19 salgını Türkiye'deki insanların hayatını nasıl etkiledi/nasıl dönüştürdü?

Grafik 7: Kronovirüsün bireysel psikolojik etkileri

Koronavirüs salgını nedeniyle aşağıdakilerden hangilerini ne sıklıkta yaşıorsunuz?

[Yakınlarını Kaybetme Korkusu]

[Belirsizlik]

[Virüsü Bulaştırma Korkusu]

[Virüsü Kapma Korkusu]

[Stres]

[Gelecek Endişesi]

[Güvensizlik]

[Ekonomik Kayg1]

[Ölüm Korkusu]

[Ümitsizlik]

[Yalnızlik]

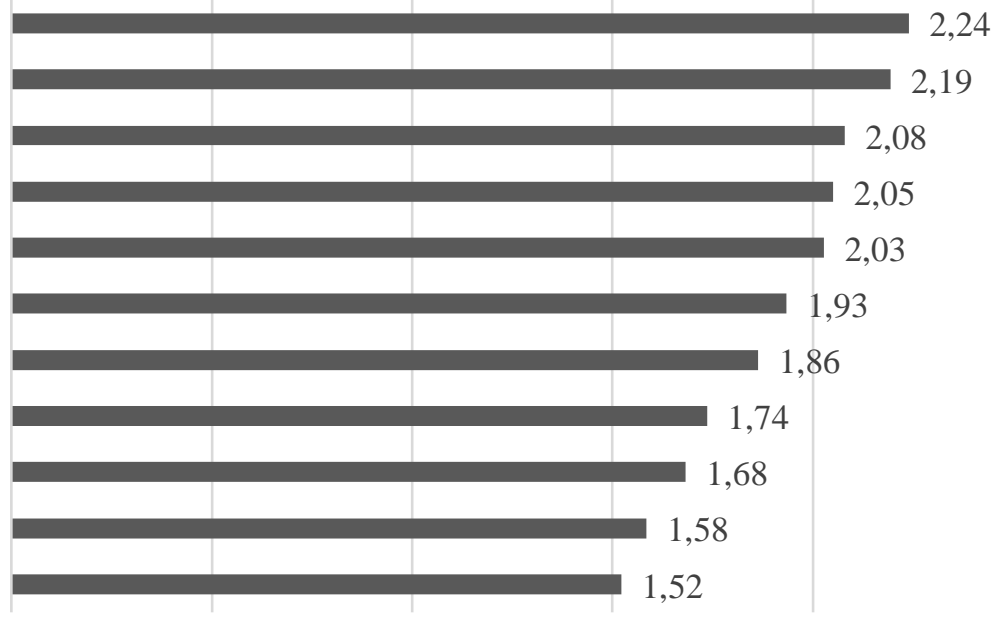

$\begin{array}{llllll}0,00 & 0,50 & 1,00 & 1,50 & 2,00 & 2,50\end{array}$


Koronavirüsün psikolojik etkilerini tespit etmek üzere katılımc1lara ne tür kaygilar ve korkular yaşadıkları sorulmuştur (Grafik 7). Çeşitli maddeler sunularak bunları ne sıklıkta yaşadıklarını belirtmeleri istenmiştir (1-Hiç, 2-Ara sıra, 3-Sık sık). Yukarıdaki grafik 7'de görüldüğü gibi ilk sırada yakınlarını kaybetme korkusu yer almaktadır. Daha sonra belirsizlik duygusunun, virüs bulaştırma korkusunun, virüs kapma korkusunun, stresin, gelecek endişesinin, güvensizlik hissinin, ekonomik kaygıların ve ölüm korkusunun geldiği görülmektedir. Ümitsizlik ve yalnızlık duygularının görülme sıklığı ise çok daha düşüktür.

Grafik 8: Koronavirüsün entellektüel ve manevi etkileri

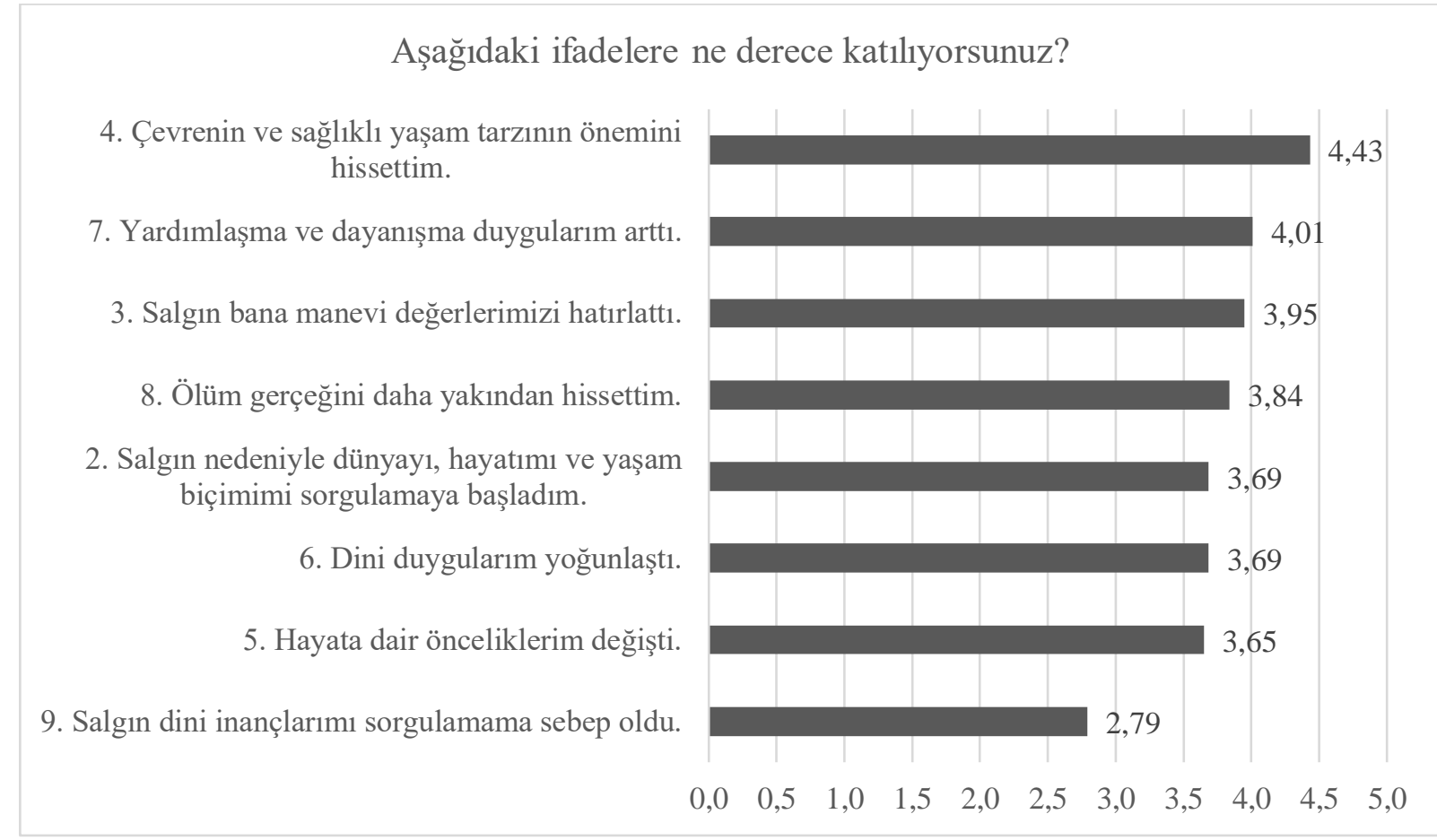

Pandeminin bireysel psikolojik etkileri yanında fikri ve manevi dönüşüme yol açıcı bir etkisi olabileceği öngörülmüştür. Bununla ilgili olarak katılımcılara bir dizi ifade verilmiş ve bunlara ne derece katıldıklarını 1'den 5'e kadar belirtmeleri istenmiştir. Burada en yüksek puana ulaşan maddenin çevrenin ve sağlıklı yaşamın kıymetine dair farkındalık olduğu görülmektedir. Katılımcılar, yardımlaşma ve dayanışma duygularının arttı̆̆ını ve salgınla birlikte manevi değerlerimizi hatırladığımızı düşünmektedir. Ayrıca salgının bize ölüm gerçeğini hatırlattığı düşünülmektedir. Katılımcılar salgın nedeniyle yaşam biçimlerini sorguladıklarını belirtseler de dini inançlarını sorguladığını söyleyenlerin oranı oldukça düşüktür. Bunun yerine hayata dair önceliklerin $\operatorname{arttığ1~ve~dini~duyguların~yoğunlaştığ~}$ 
Grafik 9: Koronavirüs salgınında kurum ve kuruluşların performanslarına ilişkin algılar

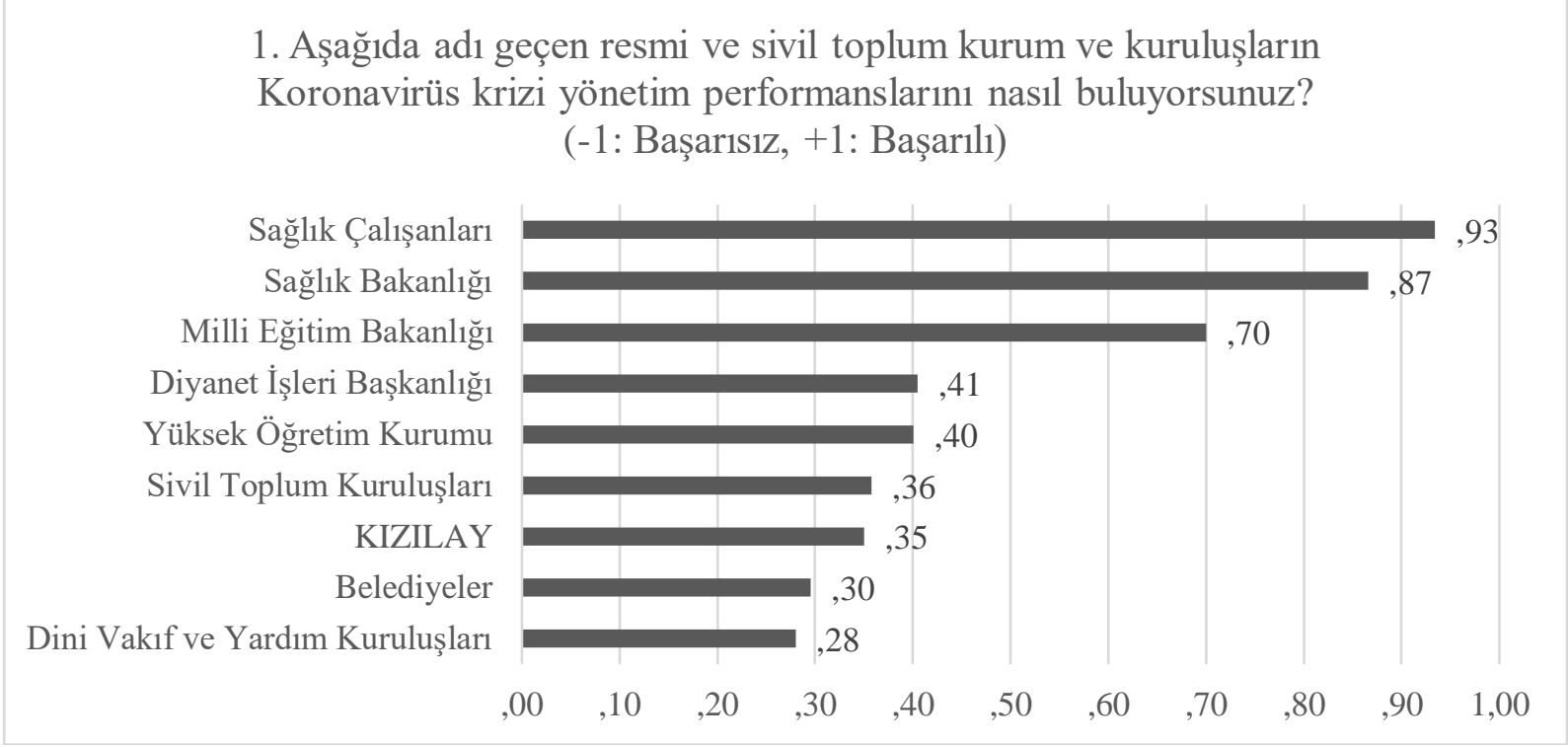

Salgın sürecinde bazı kurum ve kuruluşlara (sağlık kurumları, DİB vb.) hayati roller düştü ve bazılarının işlev ve işleyişi (MEB, YÖK, vb.) önemli ölçüde etkilendi. Katılımcılara bazı kurum ve kuruluşların performansını nasıl buldukları soruldu. Grafik 9'da görüldüğg̈ üzere, katılımcıların bu süreçte en başarılı buldukları kurum Sağlık Bakanlığı ve sağlık çalışanlarıdır. Hemen hemen katılımcıların tamamı sağlık sektörünün bu konuda başarılı olduğunu belirtmiştir. İkinci sırada ise Millı̂ Eğitim Bakanlığı gelmektedir. Diyanet İşleri Başkanlığı'nın, YÖK'ün, STK'ların, belediyelerin ve diğer dini vakıf ve yardım kuruluşlarının performansı ise nispeten daha düşük bulunmuştur.

\section{Sonuç, Tartışma ve Öneriler}

Covid-19 Salgınının ilk günlerinde Dünya ve Türkiye gündeminde meydana gelen gelişmeler ve spekülasyonlardan hareketle kamuoyunda salgının çeşitli sebeplerle yeterince ciddiye alınmadığ yönünde bir izlenim oluşmuş, buna bağlı olarak ta bireysel ve toplumsal bazda hangi tür tedbirlerin ne sıklıkta uygulanması gerekliliği konusunda bir kafa karışıklığı yaşanmıştı. Dolayısıyla, araştırmamızda merak ettiğimiz ilk sorulardan biri Türk halkının Covid-19 salgınını ne derece ciddiye alıp almadığı hususuydu.

\section{Covid-19 salgınt yeterince ciddiye altyor muyuz?}

Ulaştığımız sonuçlar, katılımcıların büyük çoğunluğunun (\%68) Koronavirüs salgınını ciddiye aldığını ve virüsün kendisine ve yakınlarına bulaşma ihtimalinden endişe duyduğunu $(\% 57,9)$ göstermektedir. Ancak bununla beraber araştırmamıza katılanların yaklaşık 1/4'nün salgını yeterince ciddiye almadığ 1 ve virüs bulaşma riskinden endişe etmediği anlaşılmaktadır (Grafik 1). Bu durum kısmen araştırmaya katılanların bazı sosyo-demografik özellikleri kısmen de salgınla ilgili medyaya yansıyan komplo teorileri ve spekülasyonlar üzerinden açıklanabilir. Öncelikle araştırmamıza katılanların büyük çoğunluğunun risk grubu $(65+$ yaş $)$ içerisinde olmadığ 1 görülmektedir. Bundan dolayı katılımcılar kendilerini risk grubunda görmediği için salgını yeterince ciddiye almamış olabilirler. Bununla beraber salgının ilk gün ve haftalarında medyaya yansıyan farklı uzman görüşleri ve komplo teorileri de konunun ciddiyetle algılanması yönünde bir tereddüt oluşturmuştur denebilir. 


\section{Türk geni taşımak, alternatif tıp veya namazında niyazında bir Müslüman olmak Koronovirüse karşı bizi korur mu?}

Yine salgının ilk günlerinde Covid-19 algısına ilişkin gündemi meşgul eden spekülasyonların başında gelen bu polemiği halkımıza sorduk. Araştırmamıza katılanların kahir ekseriyeti (\%78) Türk geninin Koronavirüse karşı dayanıklı olduğu tezini reddetmekte, neredeyse tamamı da (\%88) "namazında/niyazında olana Koronavirüs bulaşmaz" kanaatini kabul etmemektedir. Ancak, alternatif tıp konusunda ulaştığımız sonuçlar ilk ikisine göre biraz daha farklıdır. Katılımcıların bu konudaki görüşü 'katılıyorum', 'katılmıyorum' ve 'kararsız' arasında neredeyse eşit oranda bir dağılım göstermektedir. Söz konusu spekülasyonların salgının sürecinin başındaki belirsizliklerden dolayı ortaya çıkması doğal bir durumdur. Ancak, salgın sürecinin ortalarında yürütmüş olduğumuz bu araştırmadan elde ettiğimiz sonuçlar salgınla ilgili bazı belirsizliklerin ortadan kalkması, vaka ve ölüm sayılarının yükselmesi sonucunda insanların belirsizliklerden beslenen bu tür spekülasyonlardan uzaklaştığını ve daha gerçekçi düşünüp davranmaya başladığını göstermektedir.

\section{Koronavirüs salgını ilahi bir ceza mı?}

Araştırmamızın en temel amacı Covid-19 salgınının nasıl anlamlandırıldığı hususuydu. Salgın sürecinde Türkiye ve dünya gündemini meşgul eden bir başka polemik de Koronavirüs salgınının farklı anlamlandırma biçimleriydi. Medyaya ve bireysel gözlemlerimize yansıdığı nispette, bazılarının salgını doğal bir afet olarak değerlendirip herhangi bir özel anlam yüklemezken, bazılarınınsa dini anlamlandırmalar yaparak salgını bir imtihan, ilahi bir gazap veya doğanın intikamı olarak nitelendirdiğine, diğer bazılarının da salgının küresel bir komplo ve manipülasyon olarak anlamlandırdığına şahit olduk. Araştırmamız sonucunda elde ettiğimiz veriler kamuoyuna yansıyan bu tabloyu doğrulamaktadır. Katılımcıların yaklaşık üçte biri (\%30) Koronavirüs salgınının arkasında siyasi veya ekonomik küresel bir manipülasyon olduğunu, yaklaşık aynı oranda katılımcı da (\%29) salgının ilahi bir imtihan olduğunu düşünürken, sadece \%9'una göre salgın ilahi bir cezadır. $\mathrm{Bu}$ soru bağlamında, araştırmaya katılanların beşte birinden biraz fazlası (\%22) Koronavirüse doğal bir salgın olmanın dışında farklı özel bir anlam yüklemediğini ifade etmiştir.

Araştırmadan elde edilen veriler salgına dini bir anlam yükleme oranın diğer anlamlandırma biçimlerine göre daha yüksek (\%60) olduğunu göstermekle beraber, dini anlamlandırma içerisinde önemli bir farklılaşmaya işaret etmektedir. Salgına dini anlam yükleyen katılımcıların (\%60) sadece \%9,5'i salgının "ilahi bir ceza" olduğunu belirtmiştir. Geçmişte diğer doğal afetlere yüklenen anlamlarla (Küçükcan ve Köse, 2000; Kaplan, 2011) kıyaslandığında bu oran daha düşük, anlamlı ve şaşırtıcıdır. Bu ilginç bulguyu üç sebeple açıklamak mümkündür. İlk olarak, sorunun formatı dini anlam yükleme eğiliminde olan katılımcıları "imtihan" veya "ilahi bir ceza" arasında bir seçim yapmaya zorlamaktadır. Önceki araştırmaların çoğunun soru formatlarında bu ayrıştırma net bir şekilde yapıldığı söylenemez. Katılımcıların ikisi arasında seçim yaparken bu ayrıştırma üzerinde düşünerek bir tercihte bulunması bu farkı olşturmuş olabilir. "İlahi bir ceza" yüklemesi yapan \%9,5'lik bir katılımcının bilinçli bir şekilde "imtihan" yüklemesini yapabilecekken bunu tercih etmediği, yine aynı şekilde "imtihan" yüklemesi yapanların da "ilahi bir ceza" seçeneğine rağmen bilinçli bir şekilde "imtihan" tercihi yaptığ 1 anlaşılmaktadır. İkinci olarak, eğitim seviyesi faktörü burada etkili olmuş olabilir. Yapılan analizler, salgını "imtihan" olarak anlamlandıran katılımcıların "ilahi bir ceza" olarak anlamlandıranlara nazaran daha yüksek bir eğitim seviyesine sahip olduklarını göstermektedir. Son olarak, salgın riskinin mahiyeti, şiddet derecesi ve diğer afetlerden farklı olarak etkisinin zamana yayılması yapılan yükleme ve anlamlandırmanın niteliğini ve şiddetini etkilemiş olabilir. Katılımcıların büyük çoğunluğunun risk yaş grubu içerisinde olmaması, salgının etkilerinin zamana yayılması, deprem gibi yakinen hissedilmemiş olması bu sonuçta etkili olabilir. 


\section{COVID-19 salgını bir komplo mu?}

Tıpkı Kara Veba salgını ve benzer doğal afetlerde olduğu gibi, Covid-19 salgınında da medyaya yansıyan çok sayıda yerli ve yabancı komplo teorileri ileri sürüldügüne şahit olduk. Örneğin, salgın kimilerine göre Çin'in, kimilerine göre Amerika Birleşik Devletleri'nin rakiplerini yenmek için kullandığı bir biyolojik silahtı; kimilerine göre de salgının arkasında aşı satmak isteyen ilaç firmaları veya dünyayı dijitalleştirip kontrol etmek isteyen "high-tech" şirketleri vardı. Bulgular araştırmamıza katılanların 1/3'lük bir kısmının bu türden komplo teorilerine inanıp itibar ettiğini göstermektedir. Dünyada meydana gelen ve devam eden siyasi ve ekonomik olaylar ve gelişmeler, ve sosyal medyanın etkin olduğu bilgi kirliliği dikkate alındığında komplo teorisi türünden spekülasyonların gerçekliği ve inanılırlığı güç kazanmaktadır. Ayrıca, bu tür spekülasyonların ne doğruluğu ne de yanlışlığ 1 ispatlanamadığ 1 ve belirsizliklerin devam etmesinden dolayı komplo teorisi ve benzeri büyüsel düşünceler--rasyonel ve irrasyonel unsurlar içeren yarı entelektüel bir açıklama ve anlamlandırma biçimi olarak--insanlara cazip gelebilmektedir. Nitekim, araştırmamızda komplo teorisi içeren seçeneği tercih eden katılımcıların (\%30) hem eğitim hem de dindarlık seviyelerinin yüksek olduğu tespit edilmiştir. Dolayısıyla bu grubun iki farklı dini anlamlandırma seçeneğini değilde komplo teorisi içeren seçeneği tercih etmeleri, bu seçeneği -hem rasyonel hem de irrasyonel unsurlar içermesi bakımından- dini anlamlandırmadan daha makul gördükleri yönünde bir anlam çıkarmak mümkündür.

\section{Salgına karşı alınan tedbirler yeterli midir?}

Devletimiz salgınla mücadeleye ilişkin çeşitli tedbirler aldı ve almaya devam etmektedir. Halkımıza bu tedbirleri yeterli bulup bulmadıklarını sorduk. Araştırmamıza katılanların \%70'i hastanelerimizin Koronavirüsle mücadele edecek donanıma sahip olduğunu, yaklaşık yarısı da karantina tedbirlerini yeterli olduğunu düşünmektedir. Katılımcıların yaklaşı \% \%50'si ekonomik tedbirleri yeterli bulmakta ve ülkemizin Koronavirüs kaynaklı ekonomik bir krizi atlatacak güce sahip olduğunu düşünmektedir. Koronavirüsün toplumsal hafizadan silinmeyecek etkilerinden biri de alınan tedbirler çerçevesinde cuma ve cemaat namazları gibi toplu ibadetlere ara verilmesi olayı olmuştur. Her ne kadar birtakım tartışmalara neden olduysa da araştırmamıza katılanların neredeyse tamamı (\%92) Diyanet İşleri Başkanlığının aldığı bu kararı doğru bulmaktadır.

\section{Koronavirüs salgını bizi nasıl etkiledi?}

Covid-19 salgını 7'den 70'e hepimizin hayatında çeşitli izler bıraktı. Salgının muhtemel etkilerini de tespit etmeye çalıştı̆̆ımız araştırmamızda ulaştığımız sonuçlar katılımcıların büyük çoğunluğunun kendinden ziyade bir yakınını kaybetme endişesi taşıdığını, yarıdan fazlasının salgın nedeniyle dünyayı, hayatı ve yaşam biçimini sorgulamaya başladığını, hayata dair önceliklerinin değiştiğini, yaklaşık üçte ikisinin (\%70) dini duygularının yoğunlaştığını, yardımlaşma ve dayanışma duygularının arttığını göstermektedir.

\section{Koronavirüs salgınıyla nasıl başa çıkıyoruz?}

Araştırmamızın önemli üç sac ayağından birisi salgınla nasıl başa çıktığımız konusuydu. Bulgular, salgından fizyolojik olarak korunmak anlamında katılımciların neredeyse tamamının $(\% 98,6)$ "evde kal", "hijyen" ve "sosyal mesafe" gibi Koronavirüs tedbirlerine uymakta ve herkesin uyması gerektiğini ve tedbirlere uyulmamasının kul hakkı olduğunu $(\% 93,7)$ düşündüklerini göstermektedir.

Buna ek olarak, ulaştığımız sonuçlar, dinin salgını anlamlandırmada olduğu gibi salgının sebep olduğu korku-kaygı, stres gibi psikolojik durumlarla baş etmede de etkili bir rol oynadığını göstermektedir. Araştırmamıza katılanların büyük çoğunluğu (\%86) salgın süreciyle baş etmek üzere dua, ibadet ve zikir gibi dini ritüellere yöneldiği görülmektedir. Ulaşılan bu sonuç iki açıdan şaşırtıcı değil beklenen bir durumdur: (a) doğal afet ve hayatın zorlukları gibi kriz zamanlarında yaşanan çaresizliklerden dolayı insanlar genellikle ilahi bir güce yönelir, onun merhamet ve korumasına 
sığınır (Freud, 1927; Pargament, 1997). İnsanların doğasında olan bu duruma Kuran'1 Kerim'de de işaret edilmektedir: "İnsanın başına zararlı bir şey geldiğinde yan üstü yatarken veya otururken ya da ayakta iken hemen bize dua etmeye koyulur; onu zararlı durumundan kurtardığımızda ise -sanki başına gelen zararı gidermeye bizi çağırıp yalvarmamış gibi- inkârcılığa dönüp yoluna devam eder; haddi aşanlara işte bu şekilde yaptıkları güzel görünmektedir" (Yunus suresi, 12). Buna ek olarak, (b) araştırmamıza katılanların büyük çoğunluğu kendilerini orta ve üzeri bir düzeyde dindar olarak tanımlamaktadır. Dolayısıyla katılımcıların salgınla baş etmede dini ritüellere yönelmesi beklenen bir durumdur.

$\mathrm{Bu}$ çerçevede araştırmamızda elde ettiğimiz bir diğer önemli bulgu da katılımcıların neredeyse tamamına yakını $(\% 88,2)$ Koronavirüs gibi salgın ve afetlerde insanların "manevi desteğe" ihtiyaç duyduğunu ifade etmesidir. Bununla ilişkili olarak, araştırmaya katılanların yaklaşık üçte ikisi $(\% 66,6)$ de Koronavirüs gibi salgın ve benzeri afetlerde insanların dini duygu ve düşüncelerini paylaşabileceği, dini ve manevi açıdan danışmanlık yapacak bir uzmana ihtiyaç olduğunu düşünmektedir.

Kısaca özetleyecek olursak, bu araştırmada en dikkat çeken sonuçlardan birisi, doğal afet veya hastalık gibi zorlu yaşam olaylarından sonra çoğunlukla doğaüstü atıfların devreye girdiği, dini inançların olayı anlamlandırma ve olayın üstesinden gelme adına araçsallaştırıldığı ve zorlu yaşam olayıyla mücadelede dini pratiklerin önemli bir yer işgal ettiğidir. Birçok kişi bu tür durumlarda dini ve manevi desteğin gerekli olduğunu düşünmekte ve bireysel olarak bu desteği bulmaya çalışmaktadır. Ancak fiziksel sağlığı ve psikolojik sağlığı temin etmeye dönük kurumsallaşmış hizmetlerin yanında, dini ve manevi desteği sağlamaya dönük bir hizmet alanının kurumsallaşmasına ne derece ihtiyaç duyulduğu da görülmektedir. DİB bünyesinde bu faaliyetlerin yürütüldüğü ve sağlık kuruluşlarında manevi bakım hizmetlerinin verildiği bilinmektedir. Öte yandan bu tür salgınlar, doğal afetler veya diğer kitlesel yıkıcı olaylar karşısında hızlı ve organize bir şekilde manevi destek hizmetlerinin sunulabileceği ekiplerin tesis edilmesi gerekliliği ortaya çıkmaktadır.

\section{Kaynakça}

Aberth, J. (2005). The Black Death: The Great Mortality of 1348-1350, A Brief History with Documents. Bedford/St. Martin's.

Aberth, J. (2010). From the Brink of the Apocalypse: Confronting Famine, War, Plague, and Death in the Later Middle Ages. Routledge.

Alkan, M. Ö. (1999). Toplumsal ve Siyasi Açıdan 1894 Depremi Üzerine, Toplumsal Tarih, no.70, 11-17.

Bennett, J. M. ve Hollister, C. W. (2006). Medieval Europe: A Short History. McGraw-Hill.

Boccaccio, G. (1930). The Decameron vol. I (translated by Richard Aldington illustrated by Jean de Bosschere).

Byrne, J. P. (2004). The Black Death. Greenwood Press.

Foa, A. (2000). The Jews of Europe After the Black Death. (Translated by Andrea Grover). University of California Press.

Freud, S. (1961). The Future of an Illusion, Trans by. J. Strachey N: W. Norton Comp.

Gottfried, R. S. (2010). The Black Death; Natural and Human Disaster in Medieval Europe. Free Press. 
Hanawalt, B. A. (1984). "Centuries of Transition: England in the Later Middle Ages," in Richard Schlatter, ed., Recent Views on British History: Essays on Historical Writing since 1966, Rutgers University Press.

Hilton, R. H. (1974). The English Peasantry in the Late Middle Ages. Clarendon.

Horrox, R. (1994). “The Plague in Central Europe.” The Black Death. Manchester University Press.

Ibn Al-Wardi, Abu Hafs Umar (2005). "Essay on the Report of the Pestilence." The Black Death: The Great Mortality of 1348-1350, A Brief History with Documents, (edited by John Aberth). Bedford/St. Martin's.

Kaplan, H. (2011). Ilahi Adalet Psikolojisi, Express Basım Evi.

Küçükcan, T. ve Köse, A. (2000). Doğal Afetler ve Din (Marmara Depremi Üzerine Psiko-Sosyolojik Bir Inceleme). İSAM.

Krause, N., Pargament, K.I., Hill, P.C. ve Ironson, G. (2016). Humility, Stressful Life Events, And Psychological Well-Being: Findings From The Landmark Spirituality And Health Survey. The Journal of Positive Psychology, 11(5), 499-510. https://doi.org/10.1080/17439760.2015.1127991

Levy, R. S. (2005). Antisemitism: A historical encyclopedia of prejudice and persecution, Vol. 2. Santa Barbara, CA: ABC Clio.

Marshall, J. (2006). John Locke, Toleration and Early Enlightenment Culture. Cambridge University Press.

Munro, J. H. A. (2005). Before and After the Black Death: Money, Prices and Wages in FourteenthCentury England. Working papers, University of Toronto, Department of Economics.

O'Brien, J. ve Roseberry, W. (Ed.) (1991). Golden Ages, Dark Ages: Imagining the Past in Anthropology and History. University of California Press.

Pargament, K.I. (1997). The Psychologyof Religion and Coping: Theory, Research, Practice. The Guilford Press.

Scheidel, W. (2017). The Great Leveler: Violence and the History of Inequality from the Stone Age to the Twenty-First Century. Princeton University Press.

Tuchman, B. W. (1978). A Distant Mirror: The Calamitous 14th Century. Alfred A. Knopf. 